
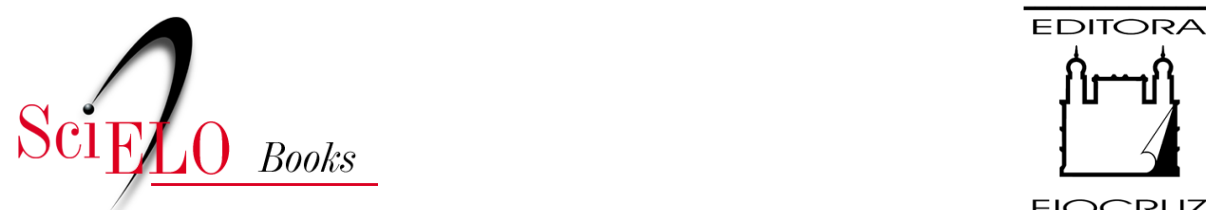

FIOCRUZ

\title{
Capítulo VII \\ A reforma da saúde pública no Congresso Nacional
}

\author{
Clementino Fraga
}

\section{SciELO Books / SciELO Livros / SciELO Libros}

FRAGA, C. A reforma da saúde pública no Congresso Nacional. In: Vida e Obra de Oswaldo Cruz [online]. 2nd ed. Rio de Janeiro: Editora FIOCRUZ, 2005, pp. 59-78. ISBN: 978-65-5708-099-3. https://doi.org/10.7476/9786557080993.0011.

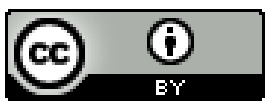

All the contents of this work, except where otherwise noted, is licensed under a Creative Commons Attribution 4.0 International license.

Todo o conteúdo deste trabalho, exceto quando houver ressalva, é publicado sob a licença Creative Commons Atribição 4.0.

Todo el contenido de esta obra, excepto donde se indique lo contrario, está bajo licencia de la licencia Creative Commons Reconocimento 4.0. 


\section{A REFORMA DA SAÜDE PÜBLICA NO CONGRESSO NACIONAL}

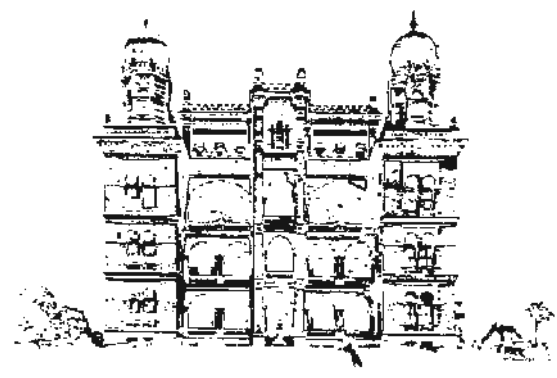

TOM a segurança de quem tem um programa a cumprir e nêle confia, sob fundamento das aquisiçōes definidas em rigorosa experimentação científica, o administrador técnico envia ao govêrno o plano de reforma dos serviços sanitários nacionais, para ser convertido em lei do país. Em 15 de junho de 1903, o Poder Executivo enviou ao Legislativo mensagem, conforme às sugestōes da autoridade sanitária:

"Entre as funçōes privativas da Diretoria-Geral de Saúde Pública figuram:

a) O estudo da natureza, etiologia, tratamento e profilaxia das moléstias transmissíveis que aparecem ou se desenvolvem em qualquer localidade da República, onde não haja recursos materiais ou serviço organizado para as pesquisas de caráter técnico ou científico, que se tornarem necessárias;

b) a prestação de socorros médicos e de higiene às populações dos Estados, a requisição dos respectivos governos, verificado o caso de calamidade pública;

c) o serviço sanitário dos portos marítimos e fluviais.

A execuçāo, mediante ordem do govêrno, de providências de higiene defensiva, em épocas anormais, contra a invasão de moléstias exóticas ou a disseminação das indígenas, na capital da República, cabia ao Instituto Sanitário Federal, que foi substituído pela Diretoria-Geral de Saúde Pública, em virtude do decreto n. ${ }^{\circ}$ 
2.458, de 10 de fevereiro de 1897 . Acidentalmente coube a êste Departamento de Higiene superintender, pela primeira vez, os serviços sanitários terrestres no Distrito Federal, quando tivemos, em 1900, a erupção da peste bubônica.

Apesar da Municipalidade dispor de uma repartição de higiene bem constituída, julgou o govêrno da União que era acertado atender à requisição do govêrno local, com o intuito de obstar a propagaçāo do mal reinante, por um conjunto harmônico de providências centralizadas, por um concêrto uniforme de medidas ditadas e executadas pela administração superior com inflexibilidade, independência e segurança de êxito.

As autoridades municipais e federais constituíram, nesta emergência, um todo homogêneo e único, e só se divorciaram depois do declínio da epidemia. Os esforços de umas e de outras ficaram, entāo, suspensos. O sucesso de providências inteligentemente combina das e dirigidas não pôde corresponder à expectativa geral, porque as duas repartições de higiene nāo mais tỉnham o direito de agir em comum, cada uma delas adstrita à esfera de suas atribuiçōes.

O intêresse comum, dos habitantes do Rio de Janeiro e de seu govêrno principal, debateu-se, daí em diante, pela conjuração urgente das funestas condiçōes de sua insalubridade, para cuja estabilidade muito ia concorrendo a dissociação dos serviços sanitários em matéria de profilaxia, a falta de conexão de providências que na prática deveriam ser sinérgicas, a quebra, enfim, de unidade de vistas e da execução de medidas que, pela sua base científica segura, pela energia administrativa que as dita, englobam o segrêdo maior da transformação sanitária de uma cidade.

A colaboração oficial não podia ser demorada. Surgiu, entāo, o decreto n. ${ }^{\circ}$ 4463 , de 12 de julho de 1902 , que teve como pedra fundamental a necessidade imperativa e inadiável de entregar à Diretoria-Geral de Saúde Pública o serviço de higiene de defesa no Distrito Federal. Esta resolução, posteriormente aprovada pelo Poder Legislativo, teve, desde os seus pródromos, o apoio incondicional do prefeito em exercício. A invasão e disseminação das moléstias exóticas e indígenas, afetando altos interêsses nacionais e estrangeiros, preocupa, instante por instante, o govêrno supremo do país.

Se já lhe cabia, nas épocas anormais, o socorro aos Estados Federais, e, em qualquer período đo ano, a direçāo sanitária dos portos marítimos e fluviais, maior tornou-se a sua órbita de responsabilidade com a faculdade, que lhe foi transferida, de organizar e superintender a polícia sanitária de defesa da capital da República. 
In teiramente ligada à higiene de defesa, de que é dependência, a polícia sanitária de defesa não pode conquistar benefícios, no ponto de vista das moléstias transmissíveis, sem o saneamento do meio local, sem a reforma das insuficientes condiçōes de salubridade dos domicílios, sem o concurso e adoçāo, finalmente, das medidas corretórias a que dá ensejo, nas visitas sistemáticas, a inspeção freqüente das habitaçōes, dos lugares e dos logradouros públicos.

A gênese de muitas anomalias nosológicas, a marcha de muitos estados mórbidos têm sua explicação científica no mau estado dos prédios habitados e desocupados, no vício orgânico das construções, na falta de atêrro e nivelamento dos terrenos e numa série de transgressōes dos preceitos de higiene doméstica, o que, favorecendo sobremodo a evolução dos mosquitos, contribui para a permanência da febre amarela entre nós.

Dificilmente pode pretender-se lucros certos de um sistema profilático que gira num círculo de providências restritivas, com dois agentes de execuçāo, um federal e outro municipal, com dualidade de competências e de orientações, com fracionamento de atribuiçōes, de prerrogativas e de intervençōes.

Em duas palavras: separação de serviços homogêneos e subdivisăo de responsabilidades técnicas indivisíveis.

Uma repartição local fazendo a higiene agressiva, enquanto a outra, da Uniăo, faz simultâneamente a higiene de defesa.

Realiza-se o desmembramento forçado de um organismo administrativo, cujas peças se completam, se subordinam e que só podem mover-se por um jôgo de combinaçōes recíprocas e nunca por solicitaçōes desiguais ou antagônicas que protestem a neutralização dos esforços despendidos.

A fusão da higiene agressiva e defensiva, separadas hoje por fronteiras abstratas, que só um espírito sutil pode conceber, é aspiração administrativa inadiável.

Por ela visa-se destruir sem delongas a complexidade num serviço público que, por sua natureza transcendente, deve primar pela simplicidade.

Também no ponto de vista da profilaxia, isto é, com o intuito de prevenir e combater as moléstias que tenham de invadir ou que existam na capital da República, não convếm ao seu govêrno deixar de associar a higiene dos portos à de terra, integrando nesta os recursos de agressão e defesa, aos quais se filiam o isolamento e a desinfecção nos casos oportunos e a política severa das habitações 
dos lugares e logradouros públicos, do primeiro ao último dia do ano, como base primordial do ataque aos focos domiciliários de moléstias transmissíveis.

Com a organizaçăo vigente, que dividiu a higiene terrestre em agressiva e defensiva, teremos que lastimar, de um lado, a ineficácia de recursos precisos para solução do problema sanitário, e, do outro lado, o aniquilamento das operosas tentativas das autoridades federais, desfeitas com um único sôpro, pela ausência da investidura executiva contra os violentadores da saúde pública.

Assim sendo, conviria que aos atuais serviços a cargo da Uniāo, constantes do art. $1 .^{\circ}$ do Regulamento a que se refere o decreto $n . .^{\circ} 2.458$, de 10 de fevereiro de 1897 , e do de $n .^{\circ} 966$, de 2 de janeiro de 1903 , fôssem adicionados os que se referem a:

- Polícia sanitária dos domicílios, logradouros públicos, podendo as autoridades sanitárias federais fazer pôr em execução as leis municipais sôbre êste assunto.

Os serviços higiênicos que merecem atualmente o małor cuidado sāo: o da profilaxia da febre amarela e o de saúde dos portos, não falando nas grandes obras de saneamento afetas ao Ministério da Indústria: abastecimento de água, canalização de esgotos, assim como o beneficiamento da zona alagadiça periurbana que confina com a baixada do Estado do Río.

A extinção da febre amarela de uma cidade é um fato que já está resolvido: o problema já foi pôsto em equação por experiências decisivas e incontestes no estrangeiro e entre nós; a solução já foi obtida pelos americanos em Cuba. Nada mais resta do que seguir as pegadas daqueles que, em cêrca de dois anos, conseguiram extirpar do solo cubano uma epidemia que dizimava ininterruptamente aquelas paragens havia séculos. É portanto um fato consumado, não nos resta mais que repetir o que já foi feito; não se trata, portanto, de um ensaio, não é uma experiência a tentar, é repetir uma coisa que jả foi experimentada com sucesso, é dar execução a um plano que já foi traçado e que, sendo seguido, dará fatalmente o mesmo resultado que deu em outras mãos, se fôr pôsto em prática nas mesmas condições. Năo é uma idéia original e nova, passivel de controvérsia, é um fato realizado, é uma idéia vitoriosa que abandonou os arraiais da hìpótese e já adquiriu os foros de fato positivo. Se os americanos conseguìram exterminar a febre amarela em cuba, não há razão para que se não consiga o mesmo entre nós. 
Conhecemos os meios postos em prática, estamos de posse das bases científicas do processo de que se lançou mão; tenhamos os meios materiais de fazê-lo, dinheiro e leis que garantam a execução das medidas, que, fatalmente, conseguiremos o mesmo fim. Pôsto o problema neste pé, resta-nos sintetizar a questāo na seguinte frase: cessará a febre amarela no Rio de Janeiro, desde que o Congresso forneça os elementos que dêle dependem. Que o govêrno disponha de dinheiro e das leis que julga necessárias, e a febre amarela no Rio será em breve um mito.

Estabelecida essa preliminar, mostremos em largos traços em que consiste a profilaxia e apontemos os meios práticos de executá-la. As verdades adquiridas e que alicerçam tôdas as medidas são as seguintes: 1 . $^{\mathrm{a}}$ - A febre amarela é produzida por um micróbio que é encontrado no sangue do doente apenas nos primeiros dias da moléstia; $2 .^{a}-$ O micróbio da febre amarela não se transmite pelos meios de contágio habituais, de homem a homem; $3 .^{a}$ - Para que se dê o contágio, é preciso que o micróbio sofra uma evolução no organismo de um hóspede intermediário, que é representado por uma espécie de mosquito, o mosquito rajado, Stegomia fasciata; $4 .^{a}$ - A febre amarela só ataca, em geral, as pessoas não imunes, que são, na regra geral, representadas pelas crianças e pelos recém-chegados ao foco em que reina a moléstia. Portanto, para que haja a febre amarela é preciso que, além das condições mesológicas necessárias à sua evolução, se congreguem os seguintes elementos: $10^{\circ}-\mathrm{o}$ micróbio da febre amarela (que se encontra no sangue do amarelento nos primeiros dias da moléstia); $2 .^{\circ}-0$ mosquito transmissor especial; $3 .^{\circ}$ - indivíduos em estado de receptividade. Assim, pois, a profilaxia da febre amarela consistirá em impedir a formação do ciclo 'micróbio-mosquitoindivíduo-receptível'. O micróbio só poderá desaparecer quando desaparecer o último a marelento e o último mosquito infectado. o primeiro passo, pois, a dar é impedir que o mosquito se infeccione no doente; portanto, quando houver doentes é preciso protegê-los contra a picada dos mosquitos, o que se pode fazer, no próprio domicílio, por meio de dispositivos especiais, que não acarretam o mínimo incômodo ao doente e à sua família, nem trazem constrangimento ao médico assistente. Mas, como o doente é sobretudo perigoso nos primeiros dias da moléstia, é de indeclinável necessidade que a autoridade sanitária tenha conhecimento dos casos o mais cedo possível. Para que se tornem efetivas essas providências, é preciso que a autoridade sanitária disponha de leis que: $1^{\circ}$ - obriguem os médicos, chefes de família etc. a comunicarem à autoridade sanitária as moléstias de 
notificação compulsória, entre as quais se acha a febre amarela; $20^{\circ}$-obriguem os Indivíduos a não se oporem às medidas de isolamento, punindo fortemente aquêles que se levantarem contra elas, ou que, protestando a melhor boa vontade, burlarem as medidas postas em prática. Assim se impedirá a contaminaçăo do mosquito.

A segunda medida profilática é o extermínio do mosquito transmissor da moléstia. Êste serviço é de suma importância e deve ser feito com a maior intensidade e extensăo nos períodos interepidêmicos; é a chamada 'campanha de inverno'. A destruiçăo dos mosquitos compōe-se de três partes: $10^{\text {a }}$ - destruiçăo do inseto adulto; $2 .^{\mathrm{a}}$ - destruiçāo das larvas e ninfas; $3 .^{\mathrm{a}}$ - destruição ou resguardo dos locais em que o mosquito adulto fecundado, em estado de hibernação, possa depositar os ovos, quando o permitirem as condiçóes do meio externo (temperatura, umidade etc.). A destruição dos mosquitos adultos deve ser feita, de preferência, nos focos da epidemia anterior, onde devem existir em estado de hibernação mosquitos infeccionados que aguardam a primeira oportunidade (elevação da temperatura, ambiente) para contaminarem os indivíduos não imunizados que por acaso encontrarem. A destruição das larvas e ninfas deve ser feita, também, ou pela destruição dos acúmulos de água em que existem, ou por outros meios adequados (querosene, creolina, cultura de certos peixes e plantas) quando essa destruição fồ impossível (lagos, riachos etc.).

A abolição dos locais em que se formam os mosquitos consiste na destruição de todo o acúmulo de água domiciliar e peridomiciliar, e essa operação deve ser repetida ao menos mensalmente, em todos os domicílios, de uma maneira sistemática, por isso que é de mais ou menos um mês o tempo que o mosquito leva para, saindo do ôvo, atingir o desenvolvimento compatível com a postura de novos ovos. Para essa 'campanha de inverno' faz-se mister um grande pessoal, constituído, sobretudo, por trabalhadores, pedreiros etc., dotados de material necessário, de modo que tôdas as casas da cidade sejam visitadas uma vez por mês e os focos de febre amarela o sejam quinzenalmente. Outrossim, é necessário que haja leis que proíbam a existência de depósitos em que se possa acumular água, assim como estabeleçam certos princípios referentes à construçăo das casas (inclinação das calhas, proteção das caixas-d'água, proibição de certos objetos de ornamentação, repuxos, tinas etc.).

Outrossim, convém também que o Congresso estabeleça uma lei severa autorizando o fechamento dos domícilios por motivo de saúde pública, autori- 
zanđo a demolição compulsória, a expensas do proprietário, pelo pessoal da higiene, assim como uma lei permitindo os melhoramentos compulsórios a expensas do proprietário.

Restam agora as medidas referentes aos indivíduos em estado de receptividade. Para isso será instalado o serviço de vigilância sanitária, que será exercitado sôbre três grupos de pessoas: $10^{\circ}$ - sôbre todos os indivíduos, receptíveis ou nāo, que estiverem em contacto com os amarelentos; $2 .^{\circ}$ - sôbre todos os indivíduos provenientes do interior da República ou dos portos nacionais ou estrangeiros que venham fixar residência na cidade do Rio de laneiro; $3 .^{\circ}$ - sôbre as crianças. Estas deverão ser protegidas por instalaçōes especiais nos estabelecimentos de habitação coletiva, como colégios, asilos etc, ou por mosquiteiros, nos domicílios particulares.

Para que tais medidas se tornem efetivas, haverá conveniência de leis que estabeleçam: $1 .^{\circ}-$ a obrigação dos indivíduos se sujeitarem à vigilância; $2 .^{\circ}-$ ao recém-chegado de indicar o domicílio e comunicar a mudança de residência; $30^{\circ}$ impedimento da entrada de imigrantes pelo pôrto do Rio de Janeiro nos meses em que costuma grassar a febre amarela; $4 .^{\circ}$ - a obrigatoriedade de instalaçōes adequadas à proteção contra os mosquitos nos colégios, asilos, hotéis, casas de pensão e outras habitaçōes coletivas que costumam obrigar viajantes, assim como de mosquiteiros ou telas de arame, nas casas particulares, ao menos nos quartos em que dormem as crianças.

Com a prática das medidas assim referidas, a febre amarela desaparecerá certamente da nossa cidade. Mas, para que as medidas lembradas possam ser postas em prática, é indispensável uma organização especial dos serviços de higiene atualmente existentes e que consistem: $1 .^{\circ}$ - aumento do pessoal que deverá ser remunerado de maneira a poder consagrar-se exclusivamente ao serviço reclamado pela Saúde Pública; $2 .^{\circ}$ - reorganização do serviço demográfico, que será a bússola indicadora não só dos focos a atacar, como também das conquistas obtidas pelo ataque ínstituído contra os focos; $3 .^{\circ}$ - a adaptaçāo de construçāo de pavilhões hospitalares adequados para o isolamento dos indigentes, ou o isolamento domiciliar; $4 .^{\circ}$ - a criaçāo de um departamento de poder judiciário, apenso à repartição de saúde pública e encarregado de processar sumàriamente as multas impostas por infração contra a saúde pública; $5 .^{\circ}-$ uma repartição de engenharia sanitária. 
Isto quanto à febre amarela.

Há ainda a atender outras medidas que merecem particular atençāo. Assim é da mais alta conveniência estabelecer-se uma severa lei sôbre vacinação e revacinação obrigatórias, moldada sôbre a célebre lei alemã de 8 de abril de 1874 , que tão benéficos resultados produziu, acabando, por assim dizer, com a varíola do Império Alemão.

Finalmente, desde já convém atender ao serviço sanitário dos portos, que é verdadeiramente vergonhoso. É imprescindível estabelecer estações de desinfecção nos principais portos, assim como hospitais de isolamento.

Como medida final, seria de grande vantagem a organização de um Código Sanitário, pelo qual fôsse regida tôda a higiene no Brasil.

Para organização dos serviços de acôrdo com as idéias acima expedidas haverá necessidade de um crédito de cinco mil e quinhentos contos $(5.500 .000 \$ 000)$ de acôrdo com a tabela anexa.

Conviria estabelecer mais que o pessoal médico encarregado da profilaxia da febre amarela fôsse considerado em comissăo. Se, porém, fồ conseguida a extinção da moléstia dentro de três anos, a contar da promulgação da última lei referente a tal serviço, o referido pessoal será considerado efetivo com os mesmos vencimentos que percebeu durante a extinção da moléstia. No caso contrário, será o pessoal extraordinário dispensado, voltando os atuais funcionários federais a perceber os antigos vencimentos.

Como medida de grande alcance prático e científico é de indeclinável necessidade a criaçāo de laboratórios anexos aos hospitais de isolamento, aos lazaretos, assim como a organização do atual Instituto Soroterápico de Manguinhos, que deverá ser transformado num instituto para o estudo de moléstias infectuosas tropicais, de acôrdo com os moldes do Instituto Pasteur, de Paris.

Ficaria êste instituto encarregado do preparo de todos os soros terapêuticos, vacinas, tratamento anti-rábico, preparo de fermentos para a indústria, do ensino da bacteriologia e parasitologia, e se transformaria num núcleo de estudos experimentais que muito concorreria para o nosso nome no estrangeiro.

A $1 .^{\circ}$ de julho de 1903, o Deputado Melo Matos apresentou o projeto da lei, na conformidade das medidas propostas e autorizando o govêrno a promulgar 
o Código Sanitário, em que eram reguladas as medidas sanitárias urbanas, higiene dos portos, exercício da medicina e farmácia, cominação de penas pelas infraçōes sanitárias etc.

A discussão do projeto, nos têrmos regimentais da Câmara, foi protelada até dezembro, entrecortada de incidentes que corriam paralelos à campanha da imprensa, como sempre acontece, com ressonância no Congresso.

A Comissão de Saúde Pública da Câmara convidou o diretor a esclarecer alguns pontos considerados excessivos. "Comparecendo, declarou o diretor de Higiene que no projeto nada havia original, era a reprodução do que se contém na legislação inglêsa e alemã, sôbre polícia sanitária; que as medidas repressivas propostas eram apenas a codificação da legislação já existente, mas não executada ainda; que se não podia prescindir da notificação compulsória, nos casos de moléstias contagiosas, nem tampouco, deixar de estabelecer a profilaxia específica peculiar a cada uma; que a lei da vacinação obrigatória contra a varíola era necessidade imperiosa - e mostrou mapas provando o desaparecimento da varíola nos países em que essa lei vigora; que a profilaxia da febre amarela só podia ser a que se adotou em Havana, com resultados decisivos, como o demonstravam as estatísticas que exibia.

Lá se verificou, ao mesmo tempo, que as desinfecções, úteis e recomendáveis em outras moléstias contagiosas, eram inteiramente inoperantes na febre amarela; ajuntou que a profilaxia da peste, ora corrente, consiste na vacinação antipestosa, na matança sistemática dos ratos, além de medidas gerais, polícia de focos, isolamento de doentes etc.

Considerava indispensável a criação do Juízo dos Feitos da Saúde Pública para que o julgamento dos infratores do regulamento sanitário se realizasse com a máxima presteza, de modo que a demora no julgamento não perturbasse o serviço. Outra medida que se impunha, dizia o diretor, era a fusão da higiene municipal na federal, a fim de que haja prontidão e unidade de ação.

Falou a seguir das vantagens da transformação do Instituto Soroterápico de Manguinhos em escola experimental, destinada ao estudo das moléstias dos nossos climas, sem prejuízo da preparação não sòmente do sôro antipestoso, mas de todos os soros e vacinas, serviço que deve ser atribuição do Instituto."

Nada obstante, o relator da comissão, médico e professor da Faculdade de Medicina, em parecer contrário, combateu as idéias do diretor, atendo-se à doutri- 
na clássica, da necessidade absoluta de desinfecção, e condenando as medidas repressivas propostas no projeto. Depois de muitas vicissitudes, em dezembro, chegou o projeto à $3 .^{\mathrm{a}}$ discussão e só a 15 foi aprovado, por 101 votos contra 35 !

No Senado, as coisas se passaram de outro modo, permitindo rápida aprovação. Em março de 1904 foi publicado o Regulamento que inaugurava normas novas e essenciais à campanha profilática.

Enquanto durou o pronunciamento do Congresso, os censores diplomados ou năo, condenavam a medida exclusiva, exortando o governo a adotar a profilaxia mista - combate ao mosquito e desinfecçâo dos focos.

Na cadeira de Higiene, da Faculdade de Medicina, o professor, com a assistência da Comissão de Saúde da Câmara, de médicos e curiosos da imprensa, proferiu três liçōes contra a doutrina havanesa. Parecia o golpe decisivo contra o prestígio da autoridade sanitária. Foi nessa ocasiāo que o Dr. Sales Guerra, temendo que os inimigos de Osvaldo Cruz lograssem influir junto ao govêrno, procurou intervir no sentido da defesa do seu amigo. Assim refere o episódio: "No mais aceso da ofensiva contra o diretor de Saúde, receoso de que o govêrno para acalmar a excitaçăo dos espíritos, em dado momento, cedesse e decidisse o restabelecimento das desinfecçöes na febre amarela, o que ímportaria na retirada de Osvaldo Cruz e no conseqüente fracasso do plano sanitário, perguntei-lhe eu se não seria de boa política, naquela apertada conjuntura, permitir as decantadas desinfecções, como desafôgo: ‘Nunca, respondeu muito senhor de si, não devo fazê-lo; estou tirando a prova da teoria havanesa; cumpre-me não alterar nenhum dos elementos do problema, para que a prova seja completa e decisiva; senăo, como concluir? Não há sinceridade nessa campanha, ajuntou; êles não se batem pela desinfecção, mas contra o Osvaldo Cruz. Se cedesse nesse ponto, inventariam outro pretexto para me hostilizar.'

Mas, V. não receia, tomei eu, que o govêrno fraqueie ante êsse clamor crescente e que ainda desta vez não consigamos libertar-nos da grande assassina?

E possível, replicou tranqüilo, mas eu não me afasto da diretriz que tracei. Theu recht und scheue niemand - ao pé da letra - age direito e não temas ninguém - era a máxima que repetia sempre, a que mais se atinha e que aplicava, resoluto, nas situaçóes delicadas.

Demais, ajuntou êle, amanhă tudo se esclarecerá: vou declarar ao govêrno que me faltam recursos monetários para continuar a campanha antiamarílica, aliás êle bem o sabe; que a oposição, em seus violentos ataques, serve-se do programa 
sanitário, que apresentei, para combater o govêrno; que contra mim clamam a imprensa, o Congresso, a ciência oficial - situação que não deve prolongar-se, desde que lhe nâo correspondam vantagens; por isso, apresento minha exoneração para não criar dificuldades ao govêrno."

Assim fêz, mas o ministro, a quem primeiro se dirigiu, declarou-lhe que "preferia cair com êle, na questāo da febre amarela".

o presidente da República estranhou o pedido, e perguntou-lhe se já não tinha fé na doutrina do mosquito...

"Fé absoluta, Sr. Presidente, mas faltam-me recursos para o pagamento dos mata-mosquitos. Até agora não foi votado o projeto de reforma da Saúde Pública em que se acha consignada a verba respectiva."

Relativamente às desinfeç̧ōes, perguntou-Ihe o presidente se estava mesmo convencido de sua inutilidade na febre amarela. "Inteiramente convencido", respondeu-lhe osvaldo Cruz. "Pois então não as faça" foi a réplica do presidente, que the prometeu providências imediatas e recursos para o prosseguimento da campanha sanitária.

Naquele tempo o govêrno prometia e cumpria.

Consagrava-se assim, pela coerência e bravura đa atituđe tếcnica, a aplicação sincera do método profilático vitorioso em Havana.

Foi nessa ocasiāo que Osvaldo Cruz publicou em artigo, dirigido à classe médica, sôbre a epidemiologia da febre amarela. Além dos dados históricos, tem ainda atualidade científica:

"A história epidemiológica da febre amarela sempre foi uma coisa misteriosa. Sendo ela uma moléstia epidêmica, notava-se, entretanto, que atacava violentamente certos pontos enquanto em outros bem próximos, e nas mesmas condições aparentes, não fazia vítimas.

Entrava đe preferência pelas casas ricas e pelos bairros límpos, poupando os bairros pobres. Senđo uma moléstia comunicável observara-se que pessoas em condiçōes de receptividade, podiam tratar e lidar com os doentes sem contraí-la, enquanto outros doentes transportados para outros lugares, ora num ponto disseminavam a moléstia, ora noutro lugar nenhum contágio provocavam. Dizia-se que ela se transmitia pelas roupas do doente e, entretanto, nos casos em que tudo parecia indicar que isso se desse, o fato não acontecia. Verificava-se, sem atinar com o motivo, que entre o primeiro caso de febre amarela numa casa, ou num navio, e os 
casos subseqüentes, havia sempre um intervalo de duas a três semanas. Via-se que a sua mortandade aumen tava ou diminuía conforme subia ou baixava a temperatura, mas isto de um modo mais sensível do que com as outras moléstias. Impressionava que a casa infectada persistisse como um foco, embora preenchendo todos os requisitos higiênicos... Nada se sabia explicar satisfatóriamente.

Tomando posse da ilha de Cuba em 1899, depois da guerra com a Espanha, o govêrno norte-americano tratou, primeiro que tudo, de saneá-la, alvejando de preferência a febre amarela, de que a ilha era um dos principais focos e de onde por várias vêzes já se tinham irradiado para os Estados Unidos, epidemias mortíferas. Foi então nomeada uma comissāo de médicos do exército norte-americano, especialmente encarregada do estudo da febre amarela e composta dos Drs. Reed, Carroll, Agramonte e Lazear; êste último adoeceu de febre logo de comêço.

Tendo em conta todos os fatos singulares que a história da febre amarela registrava e mais ainda sugestionado pela descoberta já feita de que o impaludismo era, sem nenhuma dúvida, transmitido de indivíduo a indivíduo por uma espécie particular de mosquito, a comissão que procurava, sem resultado, encontrar o germe da febre amarela julgou de melhor alvitre dirigir a sua atuaçāo mais particularmente para o seu modo de transmissão e desde logo lhe pareceu que para o seu contágio haveria um agente intermediário semelhante ao que propagava as febres intermitentes.

Da parte dos norte-americanos, era natural êste encaminhamento de idéias, porque desde 1881 que o Dr. Carlos J. Finlay, médico de origem inglêsa, residente em Cuba, tinha afirmado serem os mosquitos os transmissores do mal amarílico. Mas aos trabalhos de Finlay faltavam requisitos experimentais necessários para impor a conviç̧ão, de onde resultou que suas idéias não fôssem aceitas como demonstradas. À comissão do exército americano coube a glória de descobrir de modo indestrutível a transmissão da febre pelos mosquitos. É interessante recordar como foram feitas estas experiências brilhantes, das quais derivou a moderna teoria da profilaxia da febre amarela. Os médicos americanos se propuseram a obter a infecção de indivíduos recém-chegados a cuba e que não tinham sido atacados, por três caminhos diferentes: $1 .^{\circ}$ - pela picada de mosquitos que tivessem prèviamente mordido doente de febre amarela; $2 .^{\circ}-$ pelo contacto íntimo e prolongado com sanguessugas e mais objetos de uso do doente; $30^{\circ}$ - pela infecção de sangue retirado da veia dos enfermos. Os mosquitos utilizados nas experiênci- 
as foram da mesma espécie empregados por Finlay nos seus primeiros ensaios, o mosquito rajado denominado anteriormente culex fasciacus, ou culex mosquito e depois Stegomia fasciata. ${ }^{1}$ Para evitar qualquer suspeita quanto à proveniência dos mosquitos, êles eram criados no laboratório. Em um ensaio preliminar de onze indivíduos mordidos por mosquitos que tinham sugado o sangue do doente de febre amarela, sendo um dêles o próprio Dr. Carroll, oito tiveram febre amarela característica e com o seu prazo habitual de incubação, podendo-se excluir qualquer outro ponto de contágio.

Animado por estas provas, empreenderam as experiências definitivas. Em campo aberto, dois quilômetros de um lugar denominado Queimados, em cuba, foi criado um pôsto-sanatório experimental, além de sete barracas para o pessoal da comissão. Foram levantadas também duas construçōes, distanciada uma da outra mais de setenta metros; uma foi destinada às experiências com os mosquitos infectados, outra às experiências com roupas contaminadas. Em ambas as casas foram colocadas relas de arame nas janelas e portas duplas também de telas de arame, arranjadas de maneira que uma porta não podia ser aberta sem que a outra já estivesse fechada. Assim conseguiram que os mosquitos não entrassem ou não saíssem conforme fôsse necessário à experiência. A casa dos mosquitos contaminados era cortada ao meio por uma divisão de tela de arame impedindo o mosquito de passar de um para outro lado. Começadas as experiências, o pôsto ficou em quarentena rigorosa. Ninguém podia entrar ou sair, a nāo ser os mem bros da comissão e mais três pessoas que tinham tido a febre. A pessoa não imune que saísse năo voltava mais ao pôsto. Cada um dos indivíduos era instruído sôbre os perigos que corria com as experiências e assinava uma declaração de que se sujeitava a ela por sua livre e espontânea vontade.

As experiências foram feitas em quatorze indivíduos, soldados americanos e emigrantes espanhóis, moços não aclimados e em condiçōes de receptividade para a febre. Todos ficaram em observação durante pelo menos o prazo de incubação da moléstia e mais tempo ainda (desde seis a té setenta e oito dias) sendo examinados três vêzes por dia para se saber se alguém estava doente. Dois sómente se encontraram com febre. Um tuberculoso e outro com embaraço gástrico, sendo removído para o hospital.

\footnotetext{
' O nome atual é Aedis aegypti.
} 
Cinco dêsses indivíduos no decurso de uma semana foram sujeitos, cada um por sua vez, às picadas dos mosquitos que tinham mordido doentes de febre amarela. Quatro tiveram a infecção genuína, embora nāo mortal, tendo todos apresentado febre, dor de cabeça, dor na face e olhos, hemorragias gengivais-nasais, subicterícia, albuminuria. Cada indivíduo doente era então removido para o hospital. As cinco experiências foram feitas levando os mosquitos infeccionados às barracas em que estavam as pessoas que deviam ser picadas por êles. As experiências seguintes fizeram-se na casa dos mosquitos infeccionados do seguinte modo: essa construçāo era dividida ao meio, como dissemos, por uma tela de arame e tinha as janelas guarnecidas da mesma tela assim como a porta dupla. Nenhum mosquito podia passar de um lado para outro, nem tampouco entrar ou sair sem que a gente quisesse. Em 21 de dezembro de 1900, quinze mosquitos infeccionados de febre amarela foram soltos no compartimento maior dessa casa e aí colocada uma cama. Do outro lado foram colocadas duas camas tendo sido a roupa de cama e os próprios leitos desinfetados rigorosamente. No mesmo dia, cinco minutos depois de soltos os mosquitos no quarto, entrou nêle o indivíduo de nome Moran apenas vestido com uma camisa de dormir e aí ficou trinta minutos. Na outra divisāo entraram dois outros indivíduos para servirem de contraprova. Dois minutos depois de sua entrada foi Moran picado nas mãos e no rosto pelos mosquitos que logo pousaram sôbre êle.

Sete mosquitos o morderam desta vez. Nesse mesmo dia êle entrou de nôvo no quarto, demorando-se vinte minutos, cinco mosquitos. o quarto foi depois conservado fechado, mas os dois outros indivíduos continuaram a permanecer na outra divisão do quarto apenas separados dos mosquitos pela tela de arame. Três dias depois declarava-se a febre amarela em Moran. Os indivíduos que estavam protegidos dos mosquitos apenas pela tela de arame, embora tivessem dormido no quarto tôdas as três noites e mais três noites ainda, nada tiveram.

Tendo Moran ficado de observaçấo, antes da experiência, durante trinta e dois dias, é evidente que êle apanhou a febre amarela no quarto em que estavam os mosquitos. Seguiram-se outras experiências, em que os indivíduos a infeccionar metiam os braços nos lugares em que os mosquitos que tinham sugado sangue de amarelentos eram criados, sendo obtidas dêsse modo mais seis infeç̧ões de febre amarela, havendo sòmente um resultado negativo. Ao todo, de doze indivíduos picados pelos mosquitos infeccionados de febre amarela em condiçōes que exclu- 
íam qualquer outro modo de contágio, dez contraíram a febre amarela. Houve pois uma pequena epidemia e ocorre salientar que essa epidemia ficou estritamente limitada aos indivíduos que tinham sido picados pelos mosquitos contaminados, não tendo atacado nenhuma das sete pessoas não imunizadas existentes no pôsto experimental. A êsses dez casos apontam-se mais quatro posteriormente obtidos e temos um total de quatorze casos positivos de febre amarela produzida pela picada de mosquito infeccionado."

E, com aquela convicçāo inabalável, verdadeiramente estóica, acrescenta:

"Experiências posteriores, como veremos, comprovam êstes fatos, Estas, realizadas no pôsto sanitário de Queimados, perto de Havana, com o rigor científico a que obedeceram, não deixavam nem o vislumbre de uma dúvida ao espírito mais descrente sôbre a possibilidade da transmissão da febre amarela por intermédio do mosquito rajado denominado Stegomia fasciata. Contudo, a classe médica de Havana permaneceu incrédula até que novas experiências feitas com o mesmo rigor das primeiras pelo Dr. John Guiteras no hospital de Las Animas vieram trazer-lhe a conviç̧ão. Contra os resultados das experiências de Reed, carroll e Agramonte, havia evidentemente a objeção de que todos os casos de febre amarela obtidos pelas picadas dos mosquitos tinham sido relativamente benignos ou, pelo menos, que nenhum fôra mortal.

Embora êles tivessem sido diagnosticađos por diferentes médicos de Havana, já muito práticos em diagnosticar a febre amarela, embora nem todos os casos, em absoluto, fôssem benignos, pois alguns houve de bastante gravidade, em que os doentes ficaram entre a vida e a morte, embora nesses casos graves e ainda nos casos leves o quadro sintomático nāo permitisse hesitação, estava sempre de pé a objeção à mortalidade nula da febre amarela experimental.

Ora, nas experiências de Guiteras, de dezessete indivíduos picados pelos mosquitos infeccionados, oito contraíram a febre amarela e em três dêles manifestaram-se os sintomas gravíssimos: - supressăo de urina e vômito negro, e morte conseqüente. A autópsia, nesses três casos fatais, revelou as lesōes características da infeç̧ão.

Ao iniciar essas experiências, que tão brilhantemente confirmaram os primeiros resultados da Comissão do Exército dos Estados Unidos, não teve Guiteras em mente senāo verificar, dada a relativa benignidade da febre amarela experimental, até entăo observada, se a infecção amarílica assim provocada pelos mosquitos 
poderia ser utilizada para conseguir a imunizaçāo dos recém-chegados, sem perigo de vida para os pacientes. Só com esta esperança é que a continuação das experiências era aconselhada, porque, diz êle, 'quem quer que tivesse acompanhado sem prevenção os trabalhos dos médicos militares norte-americanos, concluiria que a solução do problema etiológico da febre amarela por êles encontrada, era definitíva'. Experiências análogas, levadas a efeito em São Paulo, por ordem do diretor do serviço sanitário, Sr. Dr. Emílio Ribas, deixam bem claro que a solução do problema é essa mesma que encontrou Guiteras, depois de Reed, Carroll e Agramonte.

Assim, por tôdas essas experiências fica concludentemente provado que se pode produzir a febre amarela em uma pessoa sã pela picada do mosquito Stegomia fasciata que prèviamente se nutriu com o sangue de um doente de febre amarela.

Mas um fato interessante se notou no decurso da experimentação: é que o mosquito, depois de picar o doente de febre amarela, não tinha o poder de transmiti-la imediatamente a outra pessoa.

Para que isto se desse necessário seria haver um outro espaço de tempo entre a picada no doente e a picada na pessoa a infeccionar.

Sempre que se empregavam mosquitos que tinham picado os doentes de febre amarela num espaço de tempo menor de onze dias, náo se conseguia a produção da febre.

Em todos os casos dessa moléstia, obtidos pela picada dos mosquitos, medeou um intervalo de onze a cinqüenta e sete dias, entre a data da picada do doente e a picada do indivíduo em experiências. Quer isto dizer que sòmente onze dias depois de haver picado o doente de febre amarela é que o mosquito adquiria o poder de transmitir a moléstia, conservando êsse poder durante um espaço, pelo menos, de cinqüenta e sete dias. Diz-se pelo menos cinqüenta e sete dias, porque se obteve um caso de febre amarela gravíssimo com um mosquito que havia picado um amarílico cinqüenta e sete dias antes e foi êsse o mosquito que mostrou maior intervalo entre as duas picadas experimentais. Contudo, um mosquito infecionado durou sessenta e nove dias, outro viveu setenta e um e assim mesmo só morreram. porque não tiveram ocasiāo de se alimentar com sangue. Estas observaçōes parecem indicar que o germe da febre amarela, depois de penetrar no corpo do mosquito com o sangue que êste suga, precisa sofrer dentro dêle certa evolução sem a qual a transmissăo não se dá. 
Êsse prazo de onze dias, no mínimo, representa sem dúvida o tempo necessário ao germe da febre amarela para poder passar do estômago do mosquito para as glândulas salivares dêle, para daí entáo ser inoculado ao homem. Outro fato que se conclui das experiências é que a picada do mosquito infecionado não vacina sem risco de vida, como acreditava Finlay e como pensam ainda certas pessoas, Os três casos fatais de Guiteras são prova convincente. A opinião de Finlay era que a picada dos mosquitos infeccionados, sem produzir a moléstia, conferia imunidade contra subseqüentes acometimentos de febre amarela.

Ora, nas experiências dos médicos norte-americanos verificou-se que um indivíduo podia ser picado uma e muitas vêzes pelos mosquitos infeccionados sem sofrer o menor desarranjo na saúde, enquanto que caía logo doente de febre amarela quando picado pelos mosquitos capazes de veicular a infecção. Em resumo: vinte e cinco casos positivos de febre amarela, quatorze de Reed, oito de Guiteras, três de São Paulo - foram produzidos pela picada dos mosquitos que antes haviam mordido doentes do mal amarílico. Provado que a febre amarela pode ser transmitida pela picada do mosquito infectado, resta saber se ela é capaz de ser adquirida de outra maneira."

\section{E, então, explica:}

"Verificado de modo evidente que a febre amarela pode ser transmitida pela picada do mosquito rajado, denominado Stegomia fasciata, resta saber se ela também se propaga por qualquer outra forma. As roupas e outros objetos do doente de febre amarela, ou provenientes de lugares em que ela existe, sempre foram considerados como a fonte principal do contágio. Muitos casos de febre amarela e até epidemias verdadeiras, eram atribuídos à abertura e revolvimento de malas e caixas contendo roupas ou outros objetos supostos infeccionados. Todos os rigores de desinfecção eram poucos para as roupas dos doentes de febre amarela ou dos indivíduos chegados de lugares infeccionados. Muitos fatos observados contradiziam êsse modo de ver exclusivo, mas, a opiniāo dominante continuava a ser a da propagaçāo da febre pelas roupas e demais objetos supostos infectados. Por isso, os médicos norte-americanos julgaram de bom conselho verificar experimentalmente a verdade do fato. No pôsto sanitário experimental de Queimados, denominado Campo Lazear, em memória do Dr. Jesse W. Lazear, falecido logo no comêço das experiências - ao lado de uma construçáo para as experiências com os mosquitos, foi edificado, como já ficou dito, em anteriores artigos, um quarto para as 
experiências com as roupas contaminadas. Êsse quarto foi disposto e preparado de modo a reunir tôdas as condições de calor, umidade, falta de arejamento e de luz e foi resguardado dos mosquitos. Colocaram-se nesse quarto diversas caixas de lençois, colchas e fronhas contaminadas pelo contato dos doentes de febre amarela, sendo alguns dêsses utensílios retirados das próprias camas dos doentes e outros propositadamente sujos com o vômito negro, as urinas e as dejeçōes dos enfermos. O Dr. R. P. Cooke e mais dois moços norte-americanos, não imunes todos, entraram, então, no quarto, abriram as caixas, remexeram e sacudiram as roupas e com os lençois, colchas e fronhas sujas, prepararam suas camas, espalhando o resto das roupas pelo quarto e no aposento assim predisposto, dormiram vinte noites a fio.

De manhã, guardava êles as roupas nas caixas, que eram de nôvo desarrumadas à noite. De dia, êsses homens podiam ficam em uma tenda próxima ao quarto, mas em rigoroso isolamento.

Uma outra caixa de roupas de cama pertencentes a doentes de febre amarela do hospital de Las Animas foi posteriormente introduzida no quarto. Essas roupas estavam também sujas de vômitos e dejeções dos enfermos e exalavam cheiro insuportável.

Em tal quarto e com tais roupas de cama dormiram aquêles três homens vinte noites seguidas, sem nenhum dêles contrair a febre amarela.

Essa experiência foi repetida mais duas vêzes, com dois indivíduos não imunes, e durante vinte e vinte e um dias de cada vez, empregando-se novos lençóis, colchas, fronhas e camisas de dormir, usados pelos doentes de febre amarela e sujos de sangue e de vômito. Nenhum ficou doente. Assim, tôdas as tentativas feitas durante sessenta e um dias para infeccionar com as roupas dos doentes, de febre amarela, o quarto e os sete indivíduos não imunes foram baldadas.

Um dêsses indivíduos depois de ter saído do quarto e ter fícado em observaçāo durante trinta dias longe das roupas contaminadas, foi sujeito às picadas dos mosquitos infeccionados e contraiu prontamente a febre amarela.

Essas experiêncías foram realizadas pela comissão do exército dos Estados Unidos composta dos Srs. Drs. Reed, Carroll e Agramonte. Como a questão era das mais importantes, os Drs. Ross e Harvard repetiram-nas por sua vez no hospital de Las Animas. 
Tôdas as tentativas que se fizeram nesta segunda série de experiências para comunicar a febre amarela por meio das roupas a oito pessoas nāo imunes foram infrutíferas, embora tais pessoas dormissem muitos dias em lençóis, fronhas e colchas usados pelos doentes e sujos de vômitos e sangue, embora vestissem as próprias camisas de dormir dos enfermos, embora desamarrassem e sacudissem tôda a espécie de roupa contaminada de febre amarela, embora as experiências fôssem feitas em Havana - um foco de febre amarela e em época propícia à epidemia. Nenhum adoeceu. Em São Paulo experiências análogas deram os mesmos resultados, conforme se vê de uma carta dirigida pelo Sr. Dr. Luís Pereira Barreto ao illustrado Sr. Dr. Duarte de Abreu e por êle transcrita em um dos excelentes artigos que publicou em O Farol, de Juiz de Fora, sôbre a teoria dos mosquitos na febre amarela.

'Posso agora afirmar-1he, diz o Sr. Dr. Luís Pereira Barreto, que a febre amarela não se propaga pelos objetos contaminados.

A nossa experiência foi feita mantendo os homens (italianos recém-chegados) por espaço de dez dias e dez noites, em uma pequena sala literalmente cheia de roupa suja, horrivelmente suja, provinda de doentes que faleceram em Santa Rita, São José e Taubaté.

Essa roupa era sacudida freqüentemente e os homens dormiam com as camisas e ceroulas cobertas de vômito prêto e enterorragias e com os lençóis e cobertores do mesmo gênero.

Saíram todos incólumes da refrega, alegres e radiantes de saúde. Nāo pode ser mais cabal a demonstração.'

Êstes fatos demonstram concludentemente que a febre amarela não é transmitida pelas roupas e mais objetos, e devem ser aceitos por todos os que se empenham sinceramente pelo conhecimento da verdade.

Năo se propagando pelas roupas e mais objetos supostos contaminados, por que outro meio se propagará a febre amarela?

É pelo meio externo infeccionado que a propagação se faz, dizia-se. Nāo é o doente que infecciona, é o lugar, afirma Scheube; a febre amarela é uma moléstia de lugares (a place disease), diz Patrick Manson. De fato, a febre amarela sempre se mostrou uma moléstia de contágio fixo. O doente de mal amarílico removido para fora do foco epidêmico, nenhum perigo de contaminação oferece, e também sempre se notou que os doentes de febre amarela removidos desta cidade para 
Petrópolis nunca propagaram a moléstia. Sabia-se que para haver propagação da infecção era preciso que o meio fôsse propício ao seu desenvolvimento e ficasse primeiro infeccionado. Dos doentes, diretamente a moléstia não passara para outras pessoas, era preciso que o contágio, saindo do doente, encontrasse no meio externo condições favoráveis e nêle permanecesse algum tempo para depois serem atacadas outras pessoas.

Não é, portanto, o doente diretamente que comunica a febre amarela. Não são as roupas e objetos maculados; é o meio infeccionado.

Mas qual é então, nesse meio infectado, o fator essencial à propagação da moléstia?

Êsse fator essencial, que não se conhecia, está hoje demonstrado que é o mosquito propagador.

Todos os fatos singulares e até então inexplicáveis da história da febre amarela encontram, assim, na doutrina vencedora da transmissão da moléstia pelos mosquitos, uma explicação natural, clara e lógica." 